症例報告 一ベストハイジニスト賞受賞—

\title{
外傷性咬合を伴った慢性歯周炎の一症例
}

\author{
長谷川沙弥 ${ }^{* 1}$, 内山美幸 ${ }^{* 1}$, 坂 井由紀 ${ }^{* 1}$, 中 村 俊 美*2 \\ 阿部祐三*2, 佐 藤 聡 $* 3$ \\ ${ }^{* 1}$ 日本歯科大学新潟病院歯科衛生科 \\ *2 日本歯科大学新潟病院総合診療科 \\ $* 3$ 日本歯科大学新潟生命歯学部歯周病学講座
}

\section{A case report of generalized chronic periodontitis with traumatic occlusion}

\author{
Saya Hasegawa*1, Miyuki Uchiyama*1, Yuki Sakai*1, Toshimi Nakamura*2 \\ Yuzo Abe ${ }^{* 2}$ and Soh Sato*3 \\ ${ }^{* 1}$ Division of Dental Hygiene, The Nippon Dental University Niigata Hospital \\ *2 Comprehensive Dental Care, The Nippon Dental University Niigata Hospital \\ ${ }^{* 3}$ Department of Periodontology, The Nippon Dental University School of Life, Dentistry at Niigata
}

\begin{abstract}
Traumatic occlusion arises from bruxism and premature contact in the course of periodontitis progression. In this paper, we report a case of localized chronic periodontitis, in which periodontal treatment was successfully undertaken considering traumatic occlusion, stability and regulation of occlusion from the early stage of periodontal treatment.

A 30-year-old woman presented to our dental hospital with hemorrhage from the gingiva at the time of brushing.

On examination, some reddening of the marginal gingiva and gingival recession were observed. Periodontal examination revealed a plaque control record (PCR) of 33.7\%, bleeding on probing (BOP) of 18.6\%, with periodontal pocket depths of greater than $4 \mathrm{~mm}$, tooth mobility of greater than class I in the molars.

On occlusal examination, occlusal trauma was observed. We started the treatment for traumatic occlusion at the same time as that for plaque control. Education on periodontitis and training on the autosuggestion method were provided by a dental hygienist, and occlusal adjustment was provided by a dentist during the periodontal therapy. Thereafter, the patient was maintained on supportive periodontal therapy (SPT).

In this case report, we wish to emphasize that treatment for traumatic occlusion at the early stage is important
\end{abstract}

連絡先：長谷川沙弥

干 951-8580 新潟県新潟市中央区浜浦町 1-8

日本歯科大学新潟病院歯科衛生科

Saya Hasegawa

Division of Dental Hygiene, The Nippon DentalUniversity NiigataHospital

1-8, Hamauracho, Chuou-ku, Niigata-city, Niigata 951-8580, Japan

E-mail : h-38.pon@ngt.ndu.ac.jp 
to obtain good results of periodontal treatment.

Nihon Shishubyo Gakkai Kaishi (J Jpn Soc Periodontol) 56(2) : 203-208, 2014.

Key words : traumatic occlusion, bruxism, initial preparation

要旨：ブラキシズム，早期接触などに起因する外傷性咬合は，歯周炎進行に深い関わりがあると言われている。 今回, 外傷性咬合を伴ったと思われる限局型慢性歯周炎患者に対し, 治療の早期段階より咬合の調整と安定に努 めた一症例を報告する。

患者は 30 歳の女性で, ブラッシング時の歯肉出血が気になり来院した。

臨床所見は臼歯部にわずかな発赤と歯肉退縮を認めた。PCR33.7\%, BOP18.6\%, 臼歯部には $4 \mathrm{~mm} 7 \mathrm{~mm}$ の 歯周ポケットと 1 度〜2 度の動摇を認めた。

咬合検査の結果, 咬合性外傷が認められたため, プラークコントロールと同時に外傷性咬合の除去を開始した。 すなわち患者教育, 自己暗示法を歯科衛生士が行い, 早期接触を認めた際は歯科医師による咬合調整を歯周外科 治療, 補綴治療時も継続して行い, SPTに移行した。

本症例は，外傷性咬合の除去を早期より行うことで，歯周炎の治療が良好に経過したと考えられる。

日本歯周病学会会誌（日歯周誌）56(2)：203-208, 2014

キーワード：外傷性咬合, ブラキシズム, 歯周基本治療

\section{緒言}

歯周治療では, 診査から歯周基本治療, SPT, メイ ンテナンスに至るまで歯科医師と歯科衛生士の連携が 重要である。とくにプラークコントロール，スケーリ ング・ルートプレーニングにおいて歯科衛生士は歯科 医師と同等の知識と技術が要求される1。つまり，歯 周治療において歯科衛生士は大きな役割を果たしてい るといえる。

プラークコントロールの確立は，歯科衛生士の果た す役割の中でも大変重要であり, これなくして治療の 効果は十分に得られない2）。しし，プラーク以外に も歯周炎を増悪させる修飾因子が存在しており，特に ブラキシズム，早期接触などに起因する外傷性咬合は 歯周炎の増悪に影響をおよぼすと考えられている3）。

今回, 咬合検査で外傷性咬合が確認されたため, 治 療の早期段階より咬合の調整と安定に努めた患者の初 診から 5 年間の経過と歯科衛生士の役割について報告 する。

なお，本症例は論文掲載にあたり患者の同意を得て いる。

\section{症例}

患 者: 性別 女性 初診時年齢 30 歳 職業 会社 員

主 訴：歯磨き時に奥歯から出血する

現病歴：3 月月ど前からブラッシング時の出血が気
になっていた。テレビで歯周病の特集を見て怖くなり 来院。

既往歴・全身既往歴：特記事項なし

口腔既往歴：大学生の時, 左側下顎臼歯部に痛みを感 じ，近医を受診。修復物はほぼこの時期に治療がなさ れた。歯科衛生士による位相差顕微鏡を用いたモチ ベーション, ブラッシング指導, 歯石除去を受けた経 験がある。

現 症 :

口腔内所見：主訴である臼歯部にわずかな発赤を認め た。 $26 \cdot 27$ に歯肉退縮を認めた。下顎前歯部舌側にわ ずかな歯肉縁上歯石を認めた。25・26の CRF 辺縁に 着色を認め, $17 \cdot 16$ 部のインレーは不適合修復であっ た。㚘粘膜および舌に圧痕を認め, 修復物・補綴物に は表面性状の変化認めた（図 1)。

エックス線画像所見：小臼歯と大臼歯に歯槽硬線の消 失と歯根膜腔の拡大を認めた。17, 16, 26, 36, 46 に 垂直性骨吸収を認めた。27に1/3 2/3 程度の水平性 骨吸収を認めた（図 2)。

歯周検査所見：PCR33.7\%, PII 0.34, BI 18.6\%, 26 歯 中 $4 \mathrm{~mm}$ 以上の歯周ポケットの割合は $12.8 \%$ あっ た。臼歯部に $4 \mathrm{~mm}$ から $7 \mathrm{~mm}$ の歯周ポケットを認 め, 36, 46 からは排膿を認めた。 27 で 2 度, 36, 47 で 1 度の動摇を認めた（図 3 )。

診 断 : 限局型重度慢性歯周炎 治療計画：

(1)歯周基本治療(モチベーション, プラークコントロー ル，スケーリング・ルートプレーニング，咬合調整， ブラキシズムに対する習癖指導, 咀嚼指導 

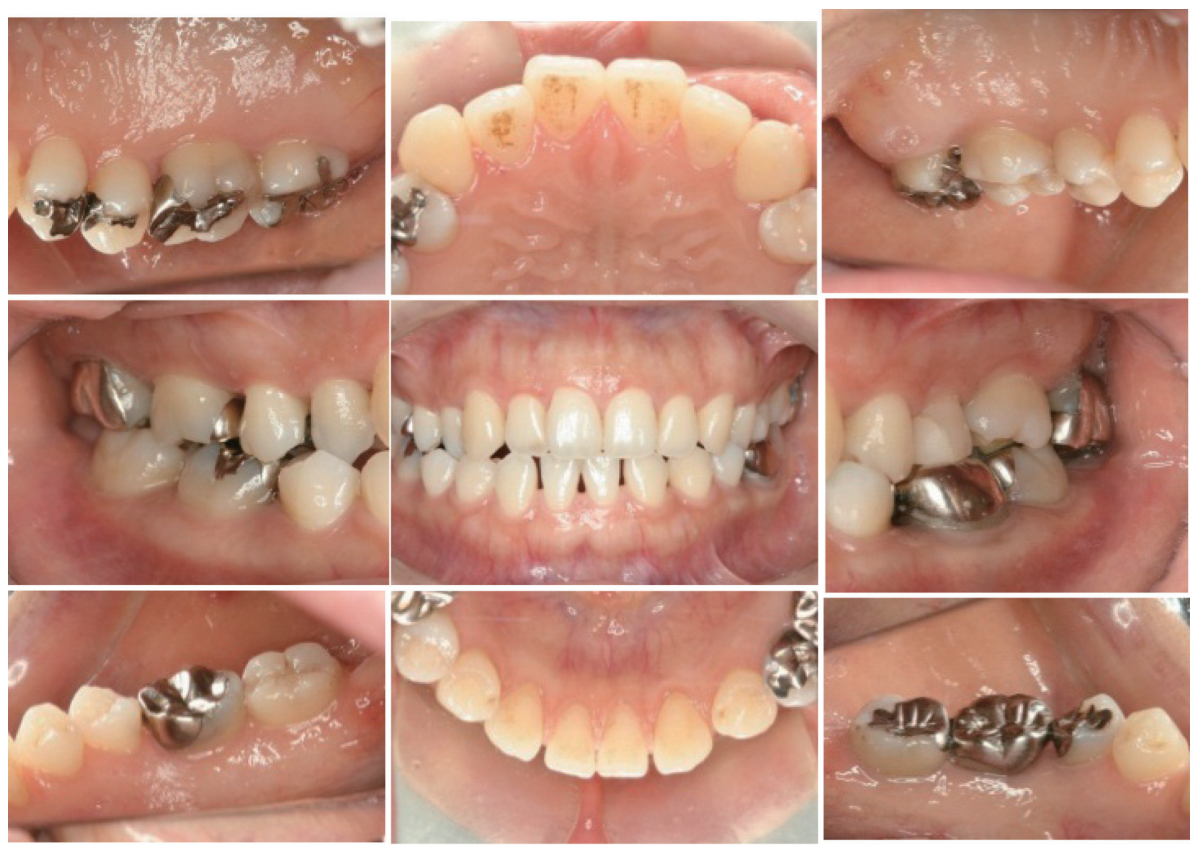

図 1 初診時の口腔内写真 (2007 年 12 月)

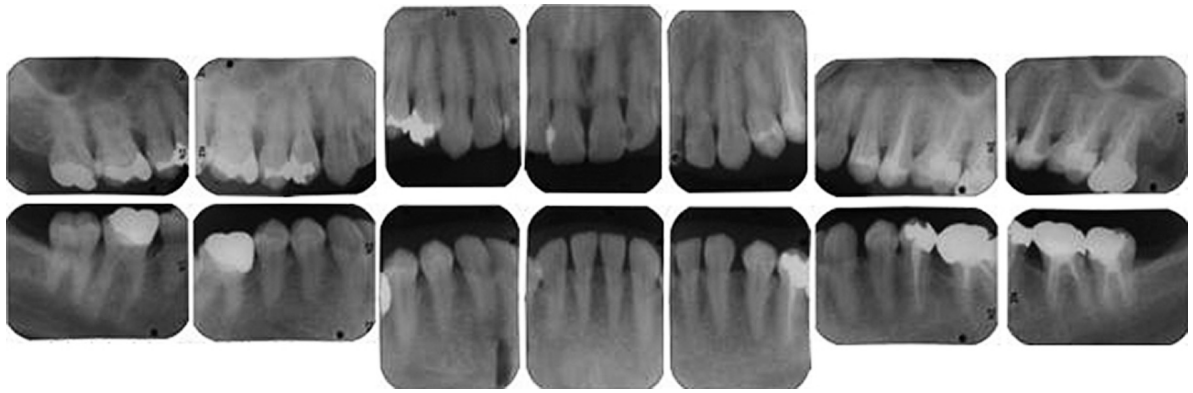

図 2 初診時のエックス線画像（2007 年 12 月）

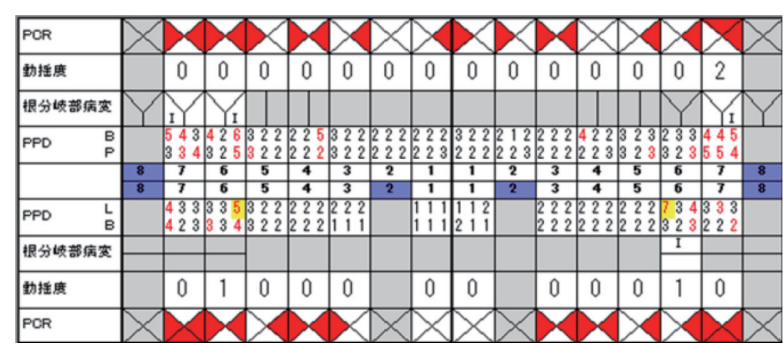

図 3 初診時歯周組織検査（2007 年 12 月）
(2)再評価
(3)歯周外科治療
(4)不適合修復物の除去，補綴治療
(5) SPT

\section{治療経過と歯科衛生士の役割}

1) 初診時, モチベーション, およびプラークコント ロールにおいて

初診時, 他院での指導内容を確認しながら歯周検査 データ, エックス線画像検査, 患者教育用冊子を用い てモチベーションを行った。患者はカリエス治療が非 常に辛かったため, 予防のため特に咬合面や歯間部の 間を意識してブラッシングしていたとのことであっ た。今後は歯周炎の進行を防ぐために, 歯肉辺縁や歯 肉溝内プラークも意識するよう説明しスクラビング法 を指導した。なお， 27 に挺出による早期接触を認めた ため咬合調整を担当医が行った。

次の来院時より歯間部のプラークコントロールを開 始した。患者は市販の糸ようじを使用していたが，た 
だ通すだけで歯肉辺縁のプラークは除去できていな かった。そこでウルトラフロス ${ }^{\circledR}$ (ライオン株式会社, 東京）の S サイズを選択し，挿入時は鋸のように，歯 間部に到達したら歯にフロスをしっかり沿わせて上下 左右に動かすように指導した。患者はすぐにテクニッ クを習得することができた。また， 口腔内所見やエッ クス線画像所見よりブラキシズムによる咬合性外傷が 疑われたため, 自己暗示法 ${ }^{4)}$ を用いたアプローチを平 行して行うこととした。

患者はブラキシズムを自覚していなかったため, ブ ラキシズムが歯や歯周組織に悪影響を与えること，歯 周炎の治療には改善が必須であることを説明し理解を 得た。まず，下顎安静位を説明し，安静空隙を体験し ていただき，次にどのような時に上下顎の歯列が接触 しているか自己観察をするよう指導した。すぐに自覚 が得られなかったため，患者が観察しやすいよう，ど のような時に上下顎歯列の接触が起こりやすいか具体 例を挙げた。その結果，イライラした時や何かに集中 している時に上下顎の歯列が触れていたとの報告が得 られた。自身で気が付いたときに安静空隙を意識する ように指導した。また，就寝時には自覚が得られな かったものの，朝起きた時に顎がだるい感じがするこ とがあるとの報告もあり就寝時のブラキシズム対策を 患者と考えた。寝る前に『歯ぎしりしないぞ!』と念 じてから寝てみると患者から提案があったため実践す るよう指導した。また，垂直に咬む，1回の咬む力を 弱くする，短時間での食事を避けるなどの咀嚼指導を 行った。

\section{2 ）スケーリング・ルートプレーニングにおいて}

スケーリング・ルートプレーニングは手用スケー ラーと超音波スケーラーを併用した。右側より左側臼 歯部に多く歯肉縁下歯石が付着していた。SRP 期間 中プラークコントロールは良好であったが，フロスに よる擦過傷を認めたため指導した。

ブラキシズムへのアプローチはどのような時に上下 顎の歯列が接触していたか毎回報告を受け，安静空隙 の確認を行った。また, ブラキシズムの発症には心因 性，ストレス性因子が関与している5)と言われている ため，診療前に近況を確認するなどコミュニケーショ ンを取るように努めた。

\section{3) 基本治療終了から最終補緅まで}

プラークコントロールは良好で, アタッチメントゲ インを認めた部位もあったが，16，27，36，46に $4 \mathrm{~mm}$ から $6 \mathrm{~mm}$ の歯周ポケットと BOP を認めた。27 の動 摇は 2 度から 1 度に減少した。ブラキシズムに関して
は，どのような時に上下顎の歯列が接触していたかの 確認や咀嚼指導を継続することでモチベーションの維 持に努めた。患者は初診時より上下顎の歯列が接触し ていることに気付く機会が増え, 咀嚼の仕方を意識し て食事をするなどの意識，行動の変化が見られた。

16，27，36，46には，エナメルマトリックスタンパ ク：エムドゲインゲル ${ }^{\circledR}$ (Straumann Japan, 東京) を 用いた再生療法が行われた。手術前はプラークコント ロールとPMTCを行い, 口腔内の細菌数を減少させ るよう努めた。また, 手術時はアシスタント業務を 行った。術後は歯肉辺縁に合わせたセルフケアの指導 と確認を行うと同時に，1２週間毎に歯肉縁上の PMTC を実施した。25は2 次う蝕を認め, 一部歯冠 が崩壊しためポーセレンクラウンを作製した。また， 17，16，26 は不適合修復であったためポーセレンイン レー,コンポジットレジン充填にて修復し, その周囲 は改めて口腔清掃指導を行った。

\section{4 ) SPT 移行から現在}

歯肉に発赤腫脹は認めず，プラークコントロールは 良好である（図 4)。エックス線画像所見では全顎的に 歯槽硬線が明瞭化し, 歯根膜腔の拡大も軽減した。17, 16，26，36，46に認めた骨吸収は若干改善した（図 5)。 また歯周検査の結果 16,26 の口蓋側に一部 $4 \mathrm{~mm}$ 程 度の歯周ポケット, 27,35 には 1 度程度の動摇が認め られるが (図 6), 病状は安定しているため, 現在は 2 か月に 1 回の来院である。外傷性咬合についてはブラ キシズムに対する指導と, 咬頭干渉や早期接触を生じ ていないかを確認している。患者はブラキシズムを自 覚しており，どのような時に上下顎の歯列が接触して いるかも把握している。また, 正しい咀嚼の方法を理 解し，意識して食事ができるようになった。ブラッシ ングは回数ではなく時間を意識し，1日 1 回ゆっくり ブラッシングを行う時間を作っているようであった。

\section{考察}

歯周炎の主要な原因は, 歯肉縁上および縁下のプ ラークであると報告され6)，良好なプラークコント ロールは歯周病の治療と予防の根幹をなす7) と言われ ている。しかし, 本症例は初診時より目立った炎症所 見がなく, プラーク付着量もさほど多くなかったため, どのような修飾因子が歯周組織の破壊に関与したの か, より早期に追及し原因除去する必要があると思わ れた。

診断は日本歯周病学会による歯周病分類システムを 用いて行われた ${ }^{8)}$ 。患者は 30 歳代と比較的若かった 

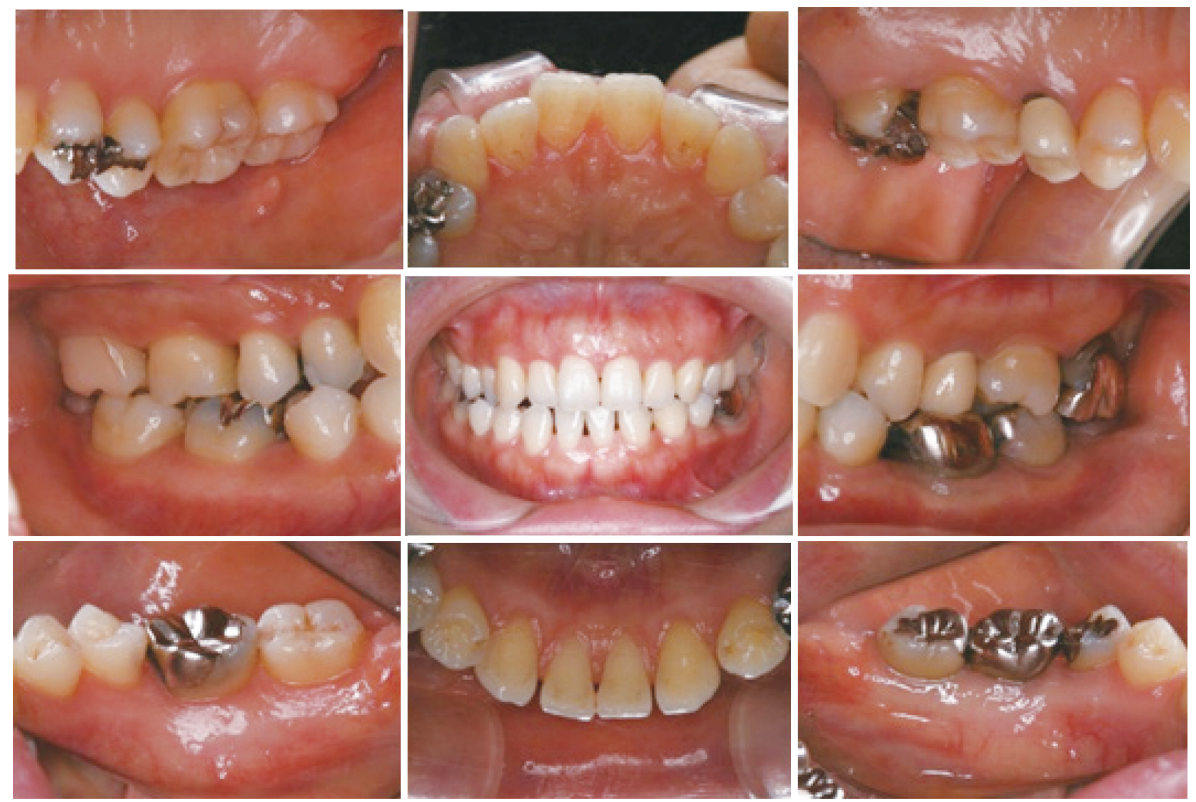

図 4 SPT 移行時の口腔内写真 (2011 年 12 月)

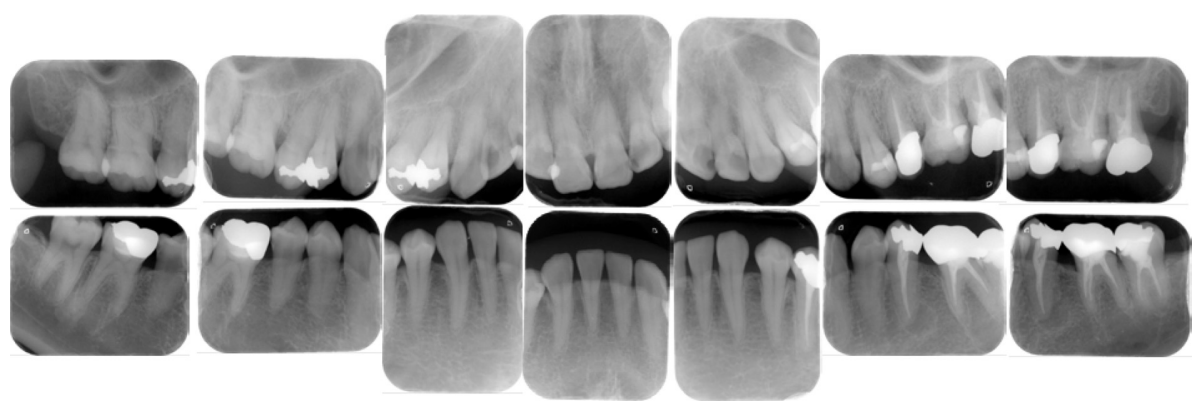

図 5 SPT 移行時のエックス線画像（2011 年 12 月）

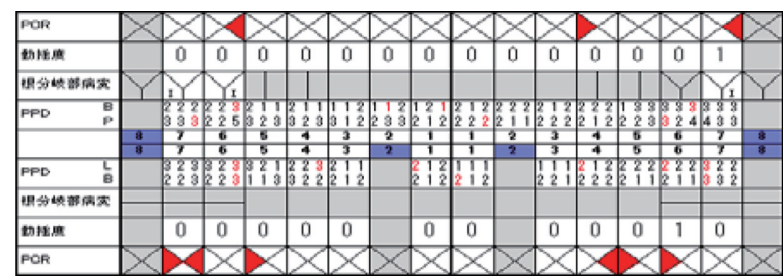

図 6 SPT 移行時歯周組織検査（2011 年 12 月）

が，急速な付着の衰失や骨吸収を認めなかったことか ら慢性歯周炎と診断された。また，歯周ポケットの形 成や一部重度の付着喪失と, 罹患率が $13.5 \%$ あっあた ため限局型と分類された。

治療計画を立案する際, ブラキシズムによる咬合性 外傷を認めた。ブラキシズムの治療の基本は, 原因と 考えられる局所因子 (早期接触などの咬合接触の異常) と全身因子（精神的ストレスなど）を取り除くことで ある ${ }^{9)}$ と報告されているため, 治療の早期段階よりこ
れらの因子除去が必要と考え，プラークコントロール と同時にブラキシズムに対する治療を開始した。ブラ キシズムへの対策はストレスや悪習癖に対する患者教 育を行って為害性を認識させ，できるだけブラキシズ

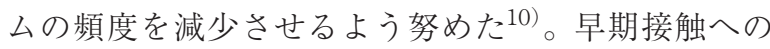
対策はフレミタスを確認し, 必要があれば咬合調整を 行った。

患者は日中の上下顎の歯列間接触を自覚しており， 行動変容ができていると思われた。初診時に認めた歯 の動摇が悪化していないことや全顎的な動摇を生じて いないこと, 知覚過敏や咬合痛, 顎関節機能障害など 患者が不快に思う症状を認めないことから，今日まで オクルーザルスプリントは作製していない。今後，必 要があれば“意識のない時に歯を守る装置”という位置 づけでの作製を考えている11)。

今回，ブラキシズムによる咬合性外傷を認め，ブラ キシズムに対するアプローチをプラークコントロール 
と同時に開始したことが歯周炎治療の良好な経過につ ながったと考えられる。しかし,力の問題については, まだエビデンスが十分に確立されていないと言われて いる ${ }^{12)}$ 。歯科衛生士として口腔内を診る力を養うこ とはもちろん，患者の訴えや症状の原因を探るための コミュニケーションが重要であると実感した。また, 患者が口腔内の問題点を理解し，積極的に治療に参加 したことがモチベーションの維持につながったと思わ れる。今後もモチベーションの維持に努め, 安定した 歯周組織を維持ができるようサポートしていきたい。

\section{謝辞}

稿を終えるにあたり，丁寧なご指導，ご助言をいただき ました先生方, 先輩歯科衛生士, 同僚歯科衛生士に心より 感謝いたします。なお，本論文の要旨は第 56 回春季日本 歯周病学会学術大会 (2013 年 5 月 31 日)に抽てポスター 発表した内容に, 一部追加, 改変して掲載いたしました。

\section{文献}

1）長谷川明, 深井浩一：歯周治療実践マニュアル一歯 科衛生士とのチームプラクティス一, 学建書院, 東 京, 1998，3。

2）特定非営利活動法人日本歯周病学会：歯周病の診断 と治療の方針 2007, 医歯薬出版株式会社, 東京, 2007, 11.
3) Svanberg G, Lindhe J : Vascular reactions in the periodontal ligament incident to trauma from occluson. J Clin Periodontol, 1 : 58-69, 1974.

4）谷口威夫：トータルから口を診みる一患者さんが自 ら治す歯科治療をめざして一, 株式会社松風, 京都, 1999, 92-96.

5）伊藤公一：咬合性外傷の話，クインテッセンス出版, 東京, 1988, 61-62.

6) Löe H, Theilade E, Jensen SB : Experimental gingivitis in man. J periodontal, $36: 177-187,1965$.

7）特定非営利活動法人日本歯周病学会：歯周病の診断 と治療の方針 2007, 医歯薬出版株式会社, 東京, 2007, 17 .

8) 特定非営利活動法人日本歯周病学会：歯周病専門用 語集, 医歯薬出版株式会社, 東京, 2006, 巻頭頁.

9) Pierce CJ, Gale EN : A comparison of different treatments for nocturnal bruxism. J dent Res, 67 : 597-601, 1988.

10）加藤熙, 坂上竜資, 畢良佳, 加藤義弘：ブラキシズ 厶と歯周治療，加藤熙，押見一，池田正彦，ブラキ シズムの基礎と臨床，日本歯科評論社，東京，1997, $177-178$.

11）内山茂：力の本, 医歯薬出版株式会社, 東京, 2012 , 62.

12）森本達也, 牛島隆, 熊谷真一：「力」によって口腔内 はどのように変化していくの?, 牛島隆, 森本達也, 熊谷真一, 市川哲雄, 月刊デンタルハイジーン別冊 知っておきたい「力」のこと一気づく・伝える守る 一, 医歯薬出版株式会社, 東京, 2010, 28. 